\title{
PENGARUH MODEL PEMBELAJARAN SELF-REGULATED LEARNING TERHADAP PRESTASI BELAJAR EKONOMI
}

\author{
Cahyana Nursidiq \\ Program Studi Pendidikan Ekonomi, Fakultas Keguruan dan Ilmu Pendidikan \\ Universitas Muhammadiah Purworejo \\ Purworejo, Indonesia \\ e-mail: cahya.umpwr@gmail.com
}

\begin{abstract}
ABSTRAK
Tujuan penelitian ini adalah untuk mengetahui pengaruh penggunaan Self-Regulated Learning terhadap prestasi belajar ekonomi, sebagai pembanding digunakan kelas kontrol model pembelajaran kooperatif tipe STAD. Penelitian ini merupakan penelitian kuantitatif dengan metode eksperimen. Pelaksanaan penelitian dimulai pada bulan Desember 2010 sampai dengan Juli 2011. Populasi penelitian meliputi seluruh siswa kelas VIII SMP Islam Al-Hadi Sukoharjo. Sampel diambil dengan menggunakan teknik simple random sampling, sebesar 30 orang siswa pada kelas VIII C untuk diberikan treatment model Self-Regulated Learning dan 30 orang siswa pada kelas VIII D untuk diberikan treatment cooperative learning metode STAD. Berdasarkan hasil analisis data, dapat disimpulkan bahwa: Terdapat perbedaan pengaruh signifikan penggunaan model pembelajaran self-regulated learning dan cooperative learning terhadap hasil belajar ekonomi siswa (nilai uji statistik $F$ sebesar 5,858 dengan nilai $p$ sebesar 0,019 ) pada taraf signifikansi $5 \%$.
\end{abstract}

Kata kunci: $\quad$ self-regulated learning, cooperative learning tipe STAD, prestasi belajar ekonomi.

\begin{abstract}
The aims of the research are to find out: The effect of self-regulated learning toward the student achievement in economics subject matter and to comparison of control class used cooperative learning with STAD methods. This study is a quantitative research with experimental method. The research begin December 2010 to July 2011. Population of the study are all the eight year students of Islam Al-Hadi junior high school in Sukoharjo. The research sample are selected with simple random sampling technique. The sample consist of VIII C (30 students) for self-regulated learning treatment and VIII D (30 students) for cooperative learning with STAD method treatment. Based on the result of analysis data was concluded: (1) There is a significant effect of self-regulated learning and cooperative learning with STAD method toward the student achievement in economics subject matter (test statistic value $F$ of 5.858 with a p-value of 0.019 ) at $5 \%$ level of significant.
\end{abstract}

Keywords: self-regulated learning, cooperative learning with STAD method, achievement of economics learning.

\section{PENDAHULUAN}

Tujuan utama dari institusi sekolah adalah terjadinya proses pembelajaran semaksimal mungkin pada diri siswa. Meski belajar dapat terjadi di mana saja, namun secara tradisional sekolah memegang peranan yang sangat penting. Mengajar merupakan salah satu sisi unik sekolah, dan karena belajar merupakan tujuan utama institusi sekolah, maka mengajar merupakan jantung dari operasi sekolah. Dengan demikian, keefektifan belajar akan sangat dipengaruhi oleh keefektifan mengajar yang terjadi.

Dengan adanya otonomi pendidikan, guru memiliki peranan yang lebih luas untuk meningkatkan kualitas pendidikan. Guru merupakan ujung tombak yang dapat menuntun keberhasilan proses belajar-mengajar yang terjadi di sekolah. Keberhasilan proses belajar siswa di sekolah tidak dapat dilepaskan dari kualitas proses pengajaran yang terjadi.

Sebagai pemimpin dalam situasi belajar mengajar, guru mempunyai fungsi sebagai perencana seluruh kegiatan belajar mengajar, mengorganisasikan seluruh elemen dalam proses tersebut, mengkoordinasikan, dan melakukan evaluasi atas proses pembelajaran sehingga dapat tercapai tujuan proses 
belajar mengajar. Pengajaran yang baik tidak hanya semata-mata menuntut penguasaan materi yang baik oleh guru, namun juga kemampuan untuk mempresentasikan informasi dengan jelas, kemampuan memotivasi siswa, dan mengevaluasi hasil belajar. Apalagi dalam konteks otonomi pendidikan, peran guru sebagai pemimpin dalam proses pembelajaran tersebut akan semakin mengemuka.

Dalam melaksanakan kegiatan belajar-mengajar, masih banyak guru yang menggunakan metode mengajar yang kurang sesuai dengan kebutuhan siswa. Penggunaan metode secara sembarangan ini tidak berdasarkan pada analisis kesesuaian antara tipe isi pelajaran dengan tipe kinerja (performasi) yang menjadi sasaran belajar. Untuk memperoleh prestasi belajar yang baik, diperlukan kondisi belajar internal dan kondisi belajar eksternal yang berbeda. Suatu metode pembelajaran seringkali hanya cocok untuk belajar tipe isi tertentu di bawah kondisi tertentu. Salah satu faktor yang menentukan keberhasilan adalah bagaimana guru mampu menerapkan pendekatan pembelajaran yang mampu membawa siswa mencapai tujuan pembelajaran.

Ada banyak model atau strategi pembelajaran yang dikembangkan oleh para ahli dalam usaha mengoptimalkan hasil belajar siswa. Banyaknya model pembelajaran yang dikembangkan tidak berarti semua pengajar menerapkan semuanya untuk setiap mata pelajaran karena tidak semua model cocok untuk setiap topik atau mata pelajaran. Sugiyanto (2009:3) menjelaskan bahwa ada beberapa hal yang perlu dipertimbangkan dalam memilih model/strategi pembelajaran, yaitu: tujuan pembelajaran yang ingin dicapai, sifat bahan/materi ajar, kondisi siswa, dan ketersediaan sarana prasarana belajar.

Dewasa ini telah banyak dikembangkan model pembelajaran yang menuntut guru maupun peserta didik lebih inovatif dalam kegiatan belajar mengajar yang dilakukan.
Sistem pembelajaran pada hampir semua pelajaran selama ini masih bersifat satu arah (Teacher Centered Learning), yaitu pemberian materi oleh guru yang ternyata membuat siswa pasif karena hanya mendengarkan pelajaran sehingga kreativitas mereka kurang terpupuk atau bahkan cenderung tidak kreatif.

Untuk dapat meningkatkan performasi pembelajaran, guru saat ini dituntut tidak hanya menjadi sumber ilmu pengetahuan tetapi lebih sebagai fasilitator dalam transfer ilmu pengetahuan kepada peserta didik. Guru memberikan motivasi agar siswa mampu mengembangkan potensi serta daya kreatifitas sehingga tujuan pembelajaran yang semula Teacher Centered Learning (TCL) menjadi Student Centered Learning (SCL).

$S C L$ adalah pembelajaran yang berpusat pada aktivitas belajar siswa, bukan hanya pada aktivitas guru yang mengajar. Guru dalam proses pembelajaran model $S C L$ memiliki peran yang penting antara lain guru bertindak sebagai fasilitator dalam proses pembelajaran, mengkaji kompetensi mata pelajaran yang perlu dikuasai siswa di akhir pembelajaran, merancang strategi dan lingkungan pembelajaran yang dapat menyediakan beragam pengalaman belajar yang diperlukan siswa dalam rangka mencapai kompetensi yang dituntut mata pelajaran, membantu siswa mengakses informasi, menata dan memprosesnya untuk dimanfaatkan dalam pemecahan permasalahan sehari hari, dan mengidentifikasi dan menentukan pola penilaian hasil belajar siswa yang relevan dengan kompetensi yang akan diukur.

$\begin{array}{lll} & \text { Dalam proses belajar mengajar } \\ \text { siswa dituntut untuk } & \text { memilki } \\ \text { kemandirian } & \text { dalam } & \text { belajar. }\end{array}$
Kemandirian tersebut dapat ditunjukkan siswa dengan cara mengorganisasikan seluruh pembelajaran yang akan dilakukan. Siswa yang dapat mengatur proses pembelajaran mereka akan cenderung lebih berhasil dalam meningkatkan prestasi akademis 
mereka. Dengan adanya kemampuan mengorganisir keterampilan metakognitif, dan mampu memotivasi diri serta memanfaatkan lingkungan belajar siswa akan cenderung lebih berhasil dalam proses pembelajaran. Salah satu model pembelajaran yang berorientasi pada Student Centered Learning (SCL) ini adalah model pembelajaran regulasi diri (SelfRegulated Learning).

Zimmerman (dalam Catherine S. Chen, 2002:12) mendefinisikan "selfregulated learners are individuals who are metacognitively, motivationally, and behaviorally active participants in their own learning process". (self-regulated learner adalah siswa yang secara metakognitif, motivasional dan behavioral merupakan peserta aktif dalam proses belajar mereka sendiri). Senada dengan hal tersebut Elizabeth A. Jordon, Marian J. Poratt (2006:8) menjelaskan "self-regulated learning includes effective strategies for learning, reflection on one's own thinking and learning (metacognition), and motivation and engagement with school tasks". (pembelajaran regulasi-diri merupakan bagian dari strategi yang efektif untuk belajar, merefleksi pada satu cara berpikir dan belajar (metakognisi), memotivasi dan melibatkan tugastugas di sekolah). Lebih lanjut Zimmerman (dalam Anita Woolfolk, 2009:130) menjelaskan "regulasi diri sebagai proses yang kita gunakan untuk mengaktifkan dan mempertahankan pikiran, perilaku, dan emosi kita untuk mencapai tujuan kita". Self-regulated learning merupakan model pembelajaran yang menekankan siswa sebagai peserta aktif dalam proses pembelajaran yang terjadi. Dengan Self-regulated learning siswa akan menjadi sadar diri akan relasi fungsional antara pola pikir dan tindakan mereka. Self-regulated learning juga mampu mengubah pandangan siswa tentang pembelajaran sebagai keterampilan dan akan digunakan untuk menganalisa tugastugas belajar, menetapkan tujuan, dan merencanakan tata cara melaksanakan tugas itu, menerapkan keterampilan, dan khususnya membuat keputusan tentang bagaimana pembelajaran akan dilaksanakan.

Model-model self-regulated learning mendeskripsikan bagaimana proses pembelajaran memilik keterampilan-keterampilan yang digunakan untuk belajar dan bagaimana mengelola faktor-faktor yang mempengaruhi belajar. Phil Winne dan Allyson Hadwin (dalam Anita Woolfolk, 2009:132) mengembangkan salah satu model self-regulated learning tersebut.

Model self-regulated learning dalam gambar di atas didasarkan pada pendapat bahwa model pembelajaran adalah agents. Agency adalah kapasitas untuk mengkoordinasikan berbagai keterampilan belajar, motivasi dan emosi untuk mencapai tujuan. Selfregulated learning menerapkan agency ketika mereka terlibat dalam siklus empat tahap utama: menganalisa tugas, menetapkan tujuan dan merancang rencana, terlibat dalam pembelajaran, dan menyesuaikan pendekatan pembelajaran. Keempat siklus tersebut dapat dijelaskan sebagai berikut:

1) Menganalisa tugas pembelajaran, Secara umum dalam tahapan ini, pembelajar memeriksa informasi apapun yang mereka anggap releven untuk mengkontruksikan sense tentang seperti apakah tugasnya, sumber daya apa yang harus dimiliki, dan bagaimana perasaanya tentang tugas yang akan dikerjakannya.

2) Menetapkan tujuan dan menyusun rencana. Mengetahui kondisikondisi yang mempengaruhi hasil kerja memberikan informasi yang digunakan oleh pembelajar untuk menetapkan tujuan belajar. Setelah iu rencana tentang bagaimana cara mencapai tujuan itu dapat dikembangkan. Memilih atau menetapkan tujuan mempengaruhi bentuk rencana pembelajaran untuk bagaimana cara belajar.

3) Menetapkan taktik dan strategi untuk menyelesaikan tugas. Selfregulated learners sangat siaga 
selama tahap ini karena mereka selalu memantau seberapa baikkah rencananya berjalan.

4) Meregulasi pembelajaran. Dalam tahap self-regulated learning ini, pembelajar mengambil keputusan tentang apakah perlu dilakukan perubahan pada ketiga tahap sebelumnya. Sebagai contoh, apabila pembelajaran lamban, apakah pembelajar harus belajar bersama siswa lain, lalu apakah siswa perlu mereview beberapa materi sebelumnya yang merupakan pondasi terhadap materi yang saat ini sedang dipelajari.

Tabel 1. Siklus Self-Regulated Learning

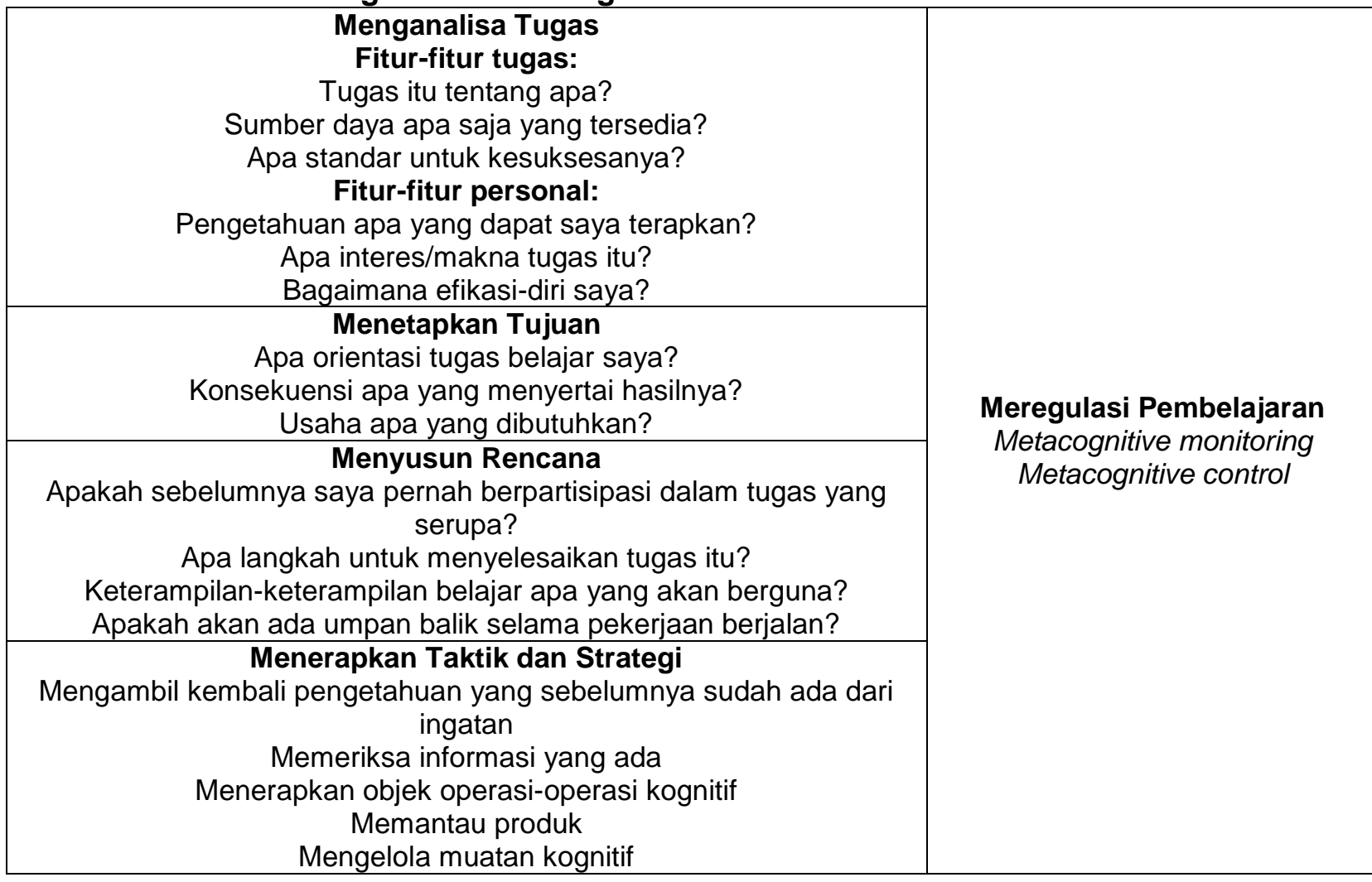

Anita Woolfolk (2009:142) menjelaskan, "dalam self-regulated learning, guru seharusnya melibatkan siswa dalam tugas-tugas yang bermakna dan kompleks yang membutuhkan waktu lama. Memberi mereka kontrol atas proses dan produk belajarnya, sehingga siswa dapat membuat pilihan-pilihan. Melibatkan siswa dalam menetapkan kriteria untuk mengevaluasi proses dan produk pembelajarannya, lalu memberi mereka kesempatan untuk menilai kemajuan dengan menggunakan standar tersebut. Terakhir, guru memberikan dorongan kepada siswa untuk bekerja secara kolaboratif dan mencari umpan balik sesaman teman".
Penggunaan teknik selfregulated learning dalam pembelajaran baik bagi pengajar dan siswa. Elizabeth A. Jordon, Marian J. Poratt (2006:8) menjelaskan "self-regulated learning includes effective strategies for learning, reflection on one's own thinking and learning (metacognition), and motivation and engagement with school tasks". (pembelajaran regulasi-diri merupakan bagian dari strategi yang efektif untuk belajar, merefleksi pada satu cara berpikir dan belajar (metakognisi), memotivasi dan melibatkan tugastugas di sekolah). Anita Woolfolk (2009:130) juga menjelaskan bahwa "self-regulated learner memiliki kombinasi keterampilan belajar 